DRAFT. PLEASE DO NOT QUOTE OR CITE.

\title{
FOOD SECURITY AND SMALL LANDHOLDERS IN SOUTH ASIA*
}

\author{
Raghbendra Jha
}

All correspondence to:

Prof. Raghbendra Jha,

Australia South Asia Research Centre,

Arndt-Corden Department of Economics,

College of Asia and the Pacific,

Australian National University,

Canberra, ACT 0200, Australia

Phone: + 6126125 2683, Fax: +61 261250443

Email: r.jha@anu.edu.au

*. I am grateful to Raj Bhatia for help with the computations and to Woojin Kang for comments. The usual disclaimer applies. 


\begin{abstract}
This paper surveys the status of food security in the South Asian countries, particularly India. Particular attention has been paid to small landholders (those households owning less than 2 hectares of land). Using NSS data from 1993-94 and 2004-05 the paper shows that small landholders are an increasing proportion of i) total rural households, ii) rural households who are poor, and iii) rural households who are undernourished. The paper then singles out five disconnects in India's recent economic performance as constituting the reason for this outcome. It advances some policy conclusions on how these disconnects can be addressed.
\end{abstract}

JEL Classification Codes : I32, O1, Q18, R20, R28

Keywords : small landholders, nutritional status, agriculture, economic growth, India 


\section{Introduction}

Food insecurity and the absence of undernutrition are often used synonymously in the literature. However, these are distinct concepts, both analytically and operationally. Having enough to eat (food security) is only one facet of having adequate nutrition. The adequacy of nutrition is spelt out in a number of indicators such as the adequate intake of macro nutrients (calorie and protein) and micronutrients (carotene, iron, riboflavin, calcium etc.) and is also expressed in anthropometric terms such as "right range of BMI" for adults and indicators of stunting and wasting in children.

That said, this paper will continue the extant practice of interpreting food insecurity as inadequate consumption of nutrition, in particular calories. For the rural sector in India the norm most often used is 2400 calories per person per day, whereas the FAO has recommended the lower cut-off point of 1700 calories. ${ }^{1}$ While this paper will occasionally present evidence on most of the South Asian countries, the primary focus will be on India.

Both access to and consumption of foodgrain have declined in India in recent times. The latest Economic Survey of the Government of India indicates that foodgrain production in India declined from $208 \mathrm{~kg}$. per annum per capita in 1996-97 to only $186 \mathrm{~kg}$ per annum per capita in 2009-10, i.e., a drop of 11 per cent. In addition India has, until recently, been exporting 7 million tonnes of grain every year. Higher real incomes lead to lower cereal demand for the rich. But, this is certainly not the case for the poor. Lower cereal demand could be an indicator of distress purchases as food demand is curtailed to enable essential non-food purchases, particularly health and education. Thus, Gaiha et al. (2010a) indicate that cereal demand in rural India fell by 9.6 per cent between 1993 and 2004. In urban India the decline was 2.6 per cent. The decline of per capita consumption is not confined to calories. It also applies to proteins and other nutrients, with the exception of fats whose consumption has increased in both rural and urban areas over this period.

Also lower food intake may be a result of higher relative prices of foodgrains, reflecting lower availability (Gaiha et al. 2010b). This also exacerbates the extent of undernourishment. As Deaton and Dreze (2009) note average calorie consumption was about 10 per cent lower

\footnotetext{
${ }^{1}$ Gopalan et al. (1971) provide details of nutritional norms for the macronutrients of calories and protein and a number of macronutrients for adult men, adult women and children and for various types of work. For adult men doing heavy work the daily calorie requirement is listed as 3900.
} 
in rural areas in 2004-05 than in 1983. ${ }^{2}$ The proportionate decline was larger among the more affluent sections of the population, and about 0 for the bottom quartile of the per capita expenditure scale. In urban areas, there was a slight change in average calorie intake over this period. Gaiha et al. (2010a) indicate that if we use the higher calorie requirement of 2400, over 71 per cent of the rural households were undernourished in 1993. With the lower intake of 1800, there is a sharp reduction to well below half the proportion (about 31 per cent), implying a large concentration of households in the calorie intake range of 1800-2400. The proportion of undernourished rises from 71 per cent to nearly 80 per cent in 2004. Also, the proportion below the lower cut-off rises from about 31 per cent to close to 37 per cent. By any standard, these imply high incidence of calorie deprivation. What is also significant is that, while the mean calorie intake of those below 1800 rose slightly (from 1491 to 1516), the mean intake of the larger concentration of households in the next higher range (1801-2400) remained about the same.

Table 1 provides some details of calorie deprivation among adults in South Asia. While the proportion of undernourished has dropped sharply in Sri Lanka and less sharply in Nepal and Bangladesh this proportion has actually increased in India and Pakistan. The absolute number of the nutritionally deficient has gone up sharply in India and Pakistan and has registered only moderate declines in the other South Asian countries.

Table 1 here.

Table 2 provides information on BMI for the South Asian countries. In their rural sectors these countries record high incidence of low BMI among females. At the same time a higher percentage of women (as compared to men) are overweight and obese.

\section{Table 2 here.}

By way of contrast Table 3 indicates the sharp progress in Infant and Child mortality in most of these countries. In Bangladesh child and infant mortality rates in 2008 fell (albeit from the highest values in South Asia) to less than half their respective magnitudes in 1990. The declines were more modest but nevertheless significant in India, Nepal, Pakistan and Sri Lanka.

\footnotetext{
${ }^{2}$ Deaton and Dreze ascribe this phenomenon to the falling need for calories in response to a more sedentary life style, which itself is a consequence of rapidly rising per capita incomes. However, Gaiha et al. (2010b) advance a complimentary explanation based on household level data for 1993-94 and 2004-05. The drop in nutrient intake is at least partially in response to an increase in the prices of these nutrients.
} 


\section{Table 3 here.}

The incidences of children being underweight, stunted or found wasting were high in all these countries with Sri Lanka being, by far, the best performers. The proportion of overweight children was high in Pakistan and less than half that magnitude in India where Bangladesh, Nepal and Sri Lanka had much smaller percentages of overweight children (Table 4).

Table 4 here.

It is instructive to contrast the performance of these economies with regard to poverty alleviation. Table 5 provides estimates of the FGT class of poverty measures for India and major states between 1983 and 2004-05 using official poverty lines for these periods.

\section{Table 5 here.}

Poverty reduction has been uneven across Indian states and over time but, in contrast to India's experience with calorie deprivation, poverty has declined steadily over time in all states, for the country as a whole and for rural and urban areas.

Data on poverty for the other South Asian countries over time are hard to come by. Mahbub ul Haq Foundation (2007) provides information on poverty in the other South Asian countries. In Bangladesh 35.6 per cent of the population lived below the national poverty line during 1984-99. During 1995-04 this percentage had climbed to 49.8. The corresponding figures for Nepal, Pakistan and Sri Lanka were 42 per cent, 34 per cent and 25 per cent respectively in 1984-99 and 30.9 per cent, 32.6 per cent and 25 per cent respectively in 1995-04. Thus the progress in poverty reduction in these countries has been more disappointing than in India.

\section{Poverty and Nutritional Status of Small Landowners}

Based on household data from the National Sample Survey (NSS) for the $50^{\text {th }}$ and $61^{\text {st }}$ rounds for 1993-94 and 2004-05 respectively Table 6 provides details of the extent of calorie undernutrition for small farming households (owing less than 2 hectares land each) for Indian states and the country as a whole.

\section{Table 6 here.}


A very large proportion of households belong to the category of small farmers in India. For the country as a whole this proportion was 86.52 per cent in 1993-94 (Column 2), which rose to 88.19 per cent in 2004-05 (Column 5). In many states this magnitude was near or even above 90 per cent in both time periods. What is important to note is that the proportion of small farming households that were poor as a proportion of total rural households was even ${ }^{3}$ higher (88.54 per cent for 1993-94 as shown in Column 3 and 91.42 per cent in 2004-05 as shown in column 6) than the share of small farming households in total rural households. Furthermore, this proportion has increased between 1993-94 and 2004-05. Similarly, small farming households constituted a higher proportion of nutritionally deficient rural households (90.23 per cent in 1993-94 as shown in Column 4 and 90.05 per cent in 2004-05 as shown in Column 7) than the shares of small farming households in total rural population in 1993-94 and 2004-05. Once again this proportion has increased between 1993-94 and 2004-05.

In the case of the incidence of poverty as well as that of undernutrition there are some regional differences but the broad conclusions remain intact.

Such undernutrition can have stark implications for labor productivity and outcomes for workers from labour markets. In Jha et al. (2009a) we test for the existence of a Poverty Nutrition Trap PNT in the case of calories and four key micronutrients - carotene, iron, riboflavin, and thiamine — for three categories of wages (sowing, harvesting, and other) and for male and female workers separately. A PNT is said to exist when undernutrition leads to low productivity, hence low wages which then translates to low nutrition, thus completing a vicious cycle.

We conclude that PNT exists in one third (i.e. 10) of the 30 cases. It exists for female harvest wage and female sowing wage for calories. In the case of carotene, male workers engaged in harvesting are subject to the PNT, whereas both male and female workers engaged in harvesting are subject to PNT in the case of iron. In the case of riboflavin female workers engaged in harvesting and sowing and male workers engaged in harvesting are subject to PNT. Since harvesting is physically more demanding than sowing, there is a higher incidence of PNT in harvesting.

Whereas the PNT holds for calories only in the cases of female sowing and female harvesting wages, it holds for males in the case of male harvesting wages (carotene, iron, and riboflavin).

\footnotetext{
${ }^{3}$ Since household size varies these number are not to be interpreted as shares in population.
} 
For females PNT holds in respect of harvesting and sowing wages for calories, thiamine, and riboflavin, PNT does not exist for females in the case of carotene, and it exists only for harvesting wages in the case of iron. Hence, an analysis which concentrates exclusively on energy intake may present an incomplete picture of the existence of PNT. This analysis shifts the focus to lack of nutritional adequacy as a precondition for participation in labour market activities. Even if some succeed in participating, their wage earnings will not allow them to escape the poverty nutrition trap. Indeed, a mild labour shock (e.g. associated with a crop shortfall) would worsen their plight, as the risk of loss of employment would be considerably higher. In particular, female workers are more prone to PNT than male workers, and there is a persistent gender inequality in rural India. We find that improving nutrient intakes can have significant effects on rural wages and, therefore, on the possibility of breaking PNT as well as reducing poverty. Thus public policy should concentrate urgently on providing direct nutritional supplements to the nutritionally deprived in addition to pursuing direct poverty alleviation policies.

Hence, rural farming households are an overwhelming proportion of the poor and nutritionally deficient households in rural India. Any public policy measure to alleviate poverty and improve nutritional outcomes in rural India must be address small farming households.

\section{Explaining the Poor Outcomes for small farmers}

A key question to be addressed then is why the incidence of poverty and that of undernutrition small landholders have been so large. At a broad level several disconnects in the Indian growth experience can be highlighted as reasons for this.

Major countries in the South Asian region have been growing quite rapidly of late (Table 7). However there is a disconnect (which we call the first disconnect) disconnect between the rate of growth of aggregate real GDP particularly in India and its most dynamic components such as manufacturing and services sector GDP on the one hand and that of agricultural GDP on the other. This is portrayed for recent years in Table 8.

\section{Tables 7 and 8 here.}


Although India's economic growth, even though high in terms of real GDP growth ${ }^{4}$ the structural composition of this growth has meant, however, that poverty reduction as a consequence of such growth has been small. (This is the second disconnect). In fact, as Table 9 indicates the poverty elasticity of India's growth is lower than that of Bangladesh, Vietnam and Sri Lanka.

Table 9 here.

We have already remarked on the fact that such growth has been associated with a drop in per capita availability of foodgrains in India (the third disconnect). We now provide some elaboration of this remark. Table 10 provides synoptic information on the performance of area, production and yield of farming activities in Indian agriculture.

\section{Table 10 here.}

The contrast between the pre-reform and the post-reform periods in respect of the performance of agriculture in the aggregate is quite stark. Even if we define the pre-reform period to go far back as the 1950s, when agricultural operations were subject to very high risks, average annual growth rates in area, production and yield for foodgrains, nonfoodgrains and all crops were higher in the period 1951-52 to 1989-90 as compared to the post-reform period 1989-90 to 2007-08. Sub-periods within and across these broad groups exhibited varying trends, with yield growth particularly high during the golden age of the Green Revolution, i.e., 1980-81 to 1989-90. This was also the golden age of poverty reduction in rural India. Table 11 provides information on the current state of crop yield. There has been substantial decline in the output of all major commodity groups: coarse cereals, cereals, pulses, foodgrains and oilseeds over the period 2007-08 to 2009-10. ${ }^{5}$

\section{Table 11 here.}

This stark conclusion about the near stagnation of productivity in Indian agriculture in the post reform period at the aggregate level can be supplemented with the figures on yields

\footnotetext{
${ }^{4}$ Per capita real GDP growth has, in recent years, been in excess of 7 per cent.

${ }^{5}$ There seems to be broad consensus among analysts that the current spate of inflation had its roots in food price inflation. The drought in 2009 led to steep rises in retail food prices followed by hikes in procurement prices for farmers. With a strengthening of the effects of the drought foodgrains had to be imported on a large scale, at prices higher than were being paid to Indian farmers. This then led to a further round of increase in the prices paid to farmers and an inflationary spiral set in. More recently, however, clear signs have emerged that inflation in the non-food sector has picked up even as food sector inflation has moderated somewhat (although still in the double digits), capacity constraints have been hit and inflationary expectations have become entrenched.
} 
reported for individual crops in Tables 12 and 13. Table 12 shows that yields for major foodgrains grew faster in the 1980s than in the post reform period. Only the performance of yield of coarse cereals has been better in the post reform period than in the pre-reform period.

Table 13 indicates that yields of various cash crops such as oilseeds, cotton and tobacco have improved during the post-reform period. However, as Table 11 indicates the performance in terms of non-cereals as a whole has been lacklustre.

\section{Tables 12 and 13 here.}

As Table 14 shows average crop yields in India are low by world standards, ${ }^{6}$ except for wheat. The performance in respect of wheat is not surprising since well over 80 per cent of the Indian wheat crop has been irrigated. The proportions in respect of the other crops are much lower. That said, by world standards a relatively high proportion of India's crops are grown with irrigation, for which there is substantial subsidy. FAO (2004) estimates that in the three years to 2002 about 21 per cent of the world's irrigated areas were found in India, although India at that point in time had only 12 per cent of the world's arable land. In the twenty year period 1980-81 to 2001-02 the area under irrigation grew from 50 million hectares (29 per cent of the area of cultivated crops) to 75 million hectares (41 per cent of the area of cultivated crops). Rice and wheat were the major irrigated crops, and at that time accounted for 32 per cent and 31 per cent of the total irrigated area respectively. During this time period overall 54 per cent of the area sown to rice is now irrigated while 88 per cent of wheat crops were irrigated. In contrast only 13 per cent and 23 per cent of the areas sown respectively to pulses and oilseeds were irrigated. Over 90 per cent of the sugar cane area, 42 per cent of the area under fruit and vegetables and a third of the cotton area were irrigated.

\section{Table 14 here.}

One of the most significant consequences of this poor growth performance in the post reform period has been the rise in unemployment in India as shown in Table 15.

\footnotetext{
${ }^{6}$ The Economic Survey for $1998-99$ suggests that India ranks $34^{\text {th }}$ in yields for Sugarcane, $57^{\text {th }}$ for Cotton, $118^{\text {th }}$ for Pulses, and, $51^{\text {st }}$ for Rice in spite of leading in production of these crops. There is also evidence of inefficient use of resources in agriculture and the resulting increased costs of agricultural production. For example 25 times more water/tonne of output is being used to irrigate cotton in India than in Egypt.
} 


\section{Table 15 here.}

The unemployment rate, on a current daily status basis, for both men and women has grown since 1993-94 and in 2005-06 was at a higher level for all categories of workers except urban females. With the much larger size of the labour force in 2005-06 as compared to 1993-94, the absolute number of the unemployed was much higher in the latter period. The paucity of jobs in the rural sector implies that the unemployed flock to the cities raising the urban unemployment growth rate as well. The National Rural Employment Guarantee Act will provide at best only 100 days of employment per eligible household which is, at best, a band-aid solution for those most in need ${ }^{7}$ and cannot be construed as a secular increase in the demand for labour which, alone, can make a serious dent on the scourge of rising unemployment in India.

Further, there is considerable inequality in access to dietary nutrition in India. FAO reports that the Gini coefficient for dietary energy consumption in India in 2004-05 was 15 per cent whereas the coefficient of variation was higher at 27per cent even as the Gini coefficient for expenditure in 2005 was 37 per cent. Such high values for the inequality indices, in particular, the value of the coefficient of variation inescapably along with lower foodgrain availability could have led to a drop in nutritional intake, most significantly in rural India, for small landholders.

One of the principal reasons for the stagnation in foodgrain production has been the stagnant investment in agriculture. This is the fourth disconnect. The performance of investment in Indian agriculture in comparison to investment in general is sketched in Figure 1.

\section{Figure 1 here.}

As Figure 1 shows, whereas investment as a proportion of GDP has been on a rising trend since the 1970s agricultural investment as a share of total investment has been falling since the 1980s. There was a mild revival between 1999-00 and 2002-03 but, since then, agricultural investment as a proportion of total investment has resumed its downward trend. This is in sharp contrast to the spurt in aggregate investment since 1999-00. Agricultural investment as a proportion of GDP has also been falling (Purohit and Reddy, 1999).

\footnotetext{
${ }^{7}$ Jha et al. (2009b) show that employment under the NREG scheme is subject to capture by the more affluent sections of Indian rural society.
} 
However, whereas investment in agriculture has been stagnant the subsidy for agriculture has risen sharply (Figure 2).

Figure 2 here.

Gulati and Narayanan (2003) report that there was a sharp rise in the level of subsidies in Indian agriculture for the period 1980-81 to 1999-00. ${ }^{8}$ By 1999-00 input subsides on fertiliser, irrigation and power alone accounted for 2.1 per cent of GDP and 8.8 per cent of agricultural output. Power subsidy made up 64 per cent of the total agricultural subsidy followed by fertiliser (22 per cent) and irrigation (14 per cent). Of course, these subsidies have had problems associated with them including losses for state electricity boards and delays in the reforms of the power sector (power subsidies), soil damage and other environmental problems (fertiliser subsidies) and salination, lowering of water table and reduction of water supply to urban areas (irrigation). It is far more important to improve technologies for rainfed agriculture. Contributing to the lower agricultural growth was the slowdown in productivity growth. Investment in agriculture was tapering off, most of it was confined to irrigated areas as it was felt that the scope for high productivity investment in rainfed agriculture was limited. About two-thirds of cultivation takes place in rainfed areas and with maximal effort this ratio would go down to at most one-half. However, there is some evidence (Fan and Hazell, 2000) pointing to the possibility of the productivity of investment being higher in rainfed areas. Thus, one important task for further research would be to identify the types of investment that hold greatest promise in the rainfed areas. We should be aware of the possibility, though, that the marginal productivity of investment in rainfed areas may be high at low levels of capital but taper off quite quickly. The combination of rising subsidies in real terms and stagnant investment implies that whereas there are resources for operational purposes (irrigation, seeds, fertilizers etc.) resources for augmenting the productive capacity of agriculture are dwindling.

Political economy considerations have been a significant factor in the rapid rise of the real value of agricultural subsidies. While some subsidies may be justified there is a widespread view that most of these subsidies are usurped by the more affluent section of farmers. Current subsidies, apart from being inefficient, have also had an inequitable impact. At the same time

\footnotetext{
${ }^{8}$ Current agricultural subsidies have continued this upward trend.
} 
they contribute to large deficits both at the central and state levels and reduce the funds available for servicing the accumulated public debt.

A further reason for the decline in nutritional outcomes is the fact that whereas nutritional intakes is sensitive to price changes (Gaiha et al. 2010b) price stabilization measures are difficult to put into effect in India. The most important reason for this is the incomplete integration of agricultural markets in India so that market shocks/price stabilization measures have imperfect flowthrough (Jha et al., 2006). (This is the fifth disconnect). For instance, the Government of India’s Ministry of Labour, Labour Bureaus estimates that while the average monthly price of rice in the country in October 2009 was recorded as Rs20.56 per kilogram, the price across 78 consumption centers ranged from Rs10.34 to Rs30.55. Figure 3 traces the mean, standard deviation and coefficient of variation of wholesale monthly rice prices in 70 centres from 1970:1 to 1999:12. As can be seen over the (unit free) coefficient of variation doubled, indicating increase in dispersion over time.

\section{Figure 3 here.}

\section{Policy Initiatives to reduce Undernutrition among small landholders in India.}

The analysis in the previous section is indicative of the multi-pronged strategy needed to reduce the incidence of hunger among small landholders. At a broad level several policy measures can be advanced, in particular to address the five disconnects referred to in this paper.

The first policy initiative must be to alter the structure of economic growth in India so that agriculture, particularly foodgrain production, grows faster. So far as the production of foodgrains is concerned attention needs to be concentrated on reversing the trend in agricultural investment and increasing investment, both public and private, in rural infrastructure including irrigation systems and rural roads. Existing water resources need to be better managed and a comprehensive strategy needs to be worked out for dryland agriculture. Investment in agricultural research also needs to be stepped up substantially and better and certified seeds need to be made available on a reliable basis. In particular, Asia Society (2010) emphasizes the role of strengthening and upgrading rice breeding and research pipelines, and accelerating research on the many varieties of rice and integrating high-yield rice and production of other crops. Such research upgrading will require a new generation of 
agricultural scientists and could be funded by a small levy of about 0.5 per cent on rice production.

There are some prerequisites for such an augmentation of foodgrain production to take place. First, farmers, including small landholders, should be willing and able to participate in the drive to increase production. Apart from the infrastructural support already alluded to small landholders would have to be given support in the areas of credit and marketing (Markelova et al., 2009). Remedial action will be needed on several fronts including increased public investment in irrigation and rural roads, better management of existing irrigation systems and of water resources in dry land areas, a strengthened agricultural research system and more effective extension, improvements in the production and distribution of certified seeds, improvements in the credit delivery system, and innovative steps in marketing and contract farming to support the diversification of Indian agriculture. In this context India's archaic India's archaic system of regulations on foodgrain markets (both wholesale and retail) needs to be urgently reformed to facilitate more effective internal trade (Kumar et al., 2010). Operations such as those of the Food Corporation of India (FCI) are quite inefficient. Kumar et al. (2010) report that the marketing costs of private traders is only about 70 per cent of the costs of the FCI. Similarly “incidental costs” for Pakistan’s Agricultural Storage and Supplies Corporations were 15-27 per cent higher for private traders in 2000-2003. State operations in foodgrains were comparably inefficient in Nepal and Sri Lanka as well. Liberalizing international trade would be beneficial for net consumers in importing countries and harmful for net producers. In this context Myers (2006) shows that food price fluctuations (partly as a consequence of government intervention in foodgrain markets) can impose major costs on food producers who also consume substantial amounts of other goods as also on poor consumers and producers "who consume lots of food, face large food price fluctuations and have high degrees of risk aversion” (Myers, 2006, p. 292). Small landholders in South Asia satisfy these criteria hence smoothing food price fluctuations through appropriate market integration and sub national regulation and tax harmonization should form a core part of the policy agenda.

Thus there is a premium on developing market-oriented food systems (Byerlee et al., 2006). In the case of India the Public Distribution Scheme (PDS) continues to have a major role to play in assuring adequate nutrition (Jha et al., 2010a). The difficulty is essentially that the 
extent of real income transfer through the PDS is only a small fraction of household income net of PDS transfers. (Jha et al., 2010b).

We also find that improving nutrient intakes can have significant effects on rural wages and, therefore, on the possibility of breaking PNT as well as reducing poverty. Thus public policy should concentrate urgently on providing direct nutritional supplements to the nutritionally deprived in addition to pursuing direct poverty alleviation policies.

\section{Conclusions}

This paper has surveyed the status of food security in the South Asian countries, particularly India. Particular attention has been paid to small landholders (those households owning less than 2 hectares of land). Using NSS data from 1993-94 and 2004-05 the paper shows that small landholders are an increasing proportion of i) total rural households, ii) rural households who are poor, and iii) rural households who are undernourished. The paper then singles out five disconnects in India's recent economic performance as constituting the reason for this outcome. It advances some policy conclusions on how these disconnects can be addressed. 


\section{References}

Asia Society (2010), 'Never an Empty Bowl: Sustaining Food Security in Asia’, Asia Society and International Rice Research Institute Task Force Report.

Byerlee, D., Jayne, T. and R. Myers (2006), 'Managing food price risks and instability in a liberalizing market environment: overview and policy options’, Food Policy 31(2), pp. 275-87.

Deaton, A. and J. Dreze (2009), 'Food and Nutrition in India: Facts and Interpretation', Economic and Political Weekly, 44(7), 42-64.

Fan, S. and P. Hazell (2000), 'Should Developing Countries Invest More in Less-Favoured Areas? An Empirical Analysis of Rural India', Economic and Political Weekly, April, pp. 1455-64.

FAO (2004), FAO STAT, database, Rome.

Gaiha, R., Jha, R. and V. Kulkarni (2010a), 'Prices, Expenditure and Nutrition in India’, Working Paper 2010/15, Australia South Asia Research Centre, Australian National University, Canberra.

Gaiha, R., Jha, R. and V. Kulkarni (2010b), ‘Demand for Nutrients in India, 1993-2004', Working Paper 2010/16, Australia South Asia Research Centre, Australian National University, Canberra.

Gopalan C, Sastri B., Balasubramanian S. (1971) Nutritive Value of Indian Foods. National Institute of Nutrition: Indian Council of Medical Research: Hyderabad.

Gulati, A. and S. Narayanan (2003), Subsidy Syndrome in Indian Agriculture, New Delhi: Oxford University Press.

Himanshu (2007), 'Recent Trends in Poverty and Inequality: Some preliminary results', Economic and Political Weekly, 42(6), 497-508, 10 February.

Mahbub ul Haq Human Development Centre (2007), Human Development Report in South Asia — A Ten year Review: Islamabad, Pakistan, Oxford University Press

IFPRI (International Food Policy Research Institute) (2010), ‘Tackling the Agriculture-Nutrition Disconnect in India (TANDI): What do we know and what do we need to know' mimeo.

Jha, R., Murthy, K.V.B and A. Sharma (2006), 'Market Integration in Wholesale Rice Markets in India’ Economic and Political Weekly, 40(53), 5571-7.

Jha, R., Gaiha, R. \& A. Sharma (2009a), 'Calorie and Micronutrient Deprivation and Poverty Nutrition Traps in Rural India', World Development, 37(5), 982-91. 
Jha, R., Bhattacharyya, S., Gaiha, R. and S. Shankar (2009b), “ “Capture” of Anti-poverty programs: An Analysis of the National Rural Employment Guarantee Program in India', Journal of Asian Economics, vol.20, pp. 456-64.

Jha, R., Bhattacharyya, S., and R.Gaiha (2010a), 'Social Safety Nets and Nutrient Deprivation: An Analysis of the National Rural Employment Guarantee Program and the Public Distribution System in India', Working Paper 2010/4, Australia South Asia Research Centre, Australian National University, Canberra.

Jha, R., Gaiha, R. and M. Pandey (2010b), 'Food Price Subsidy under Public Distribution System in Andhra Pradesh, Maharashtra and Rajasthan’, Working Paper 2010/7, Australia South Asia Research Centre, Australian National University, Canberra.

Kumar, G., Roy, D. and A. Gulati (2010), ‘Liberalizing Foodgrains Markets: Experiences, Impact and Lessons from South Asia’, IFPRI Issue Brief 64, August.

Markelova, H., Meinzen-Dick, R., Hellin, J. and S. Dohrn (2009), 'Collective Action for Smallholder Market Access', Food Policy, 34(1), pp. 1-7.

Mullen, K., Orden, D. and A. Gulati (2005), 'Agricultural Policies in India: Producer Support Estimates 1985-2002', MTID Discussion Paper No. 82, IFPRI, Washington D.C.

Myers, R. (2006), 'On the Costs of Food Price Fluctuations in Low-Income Countries', Food Policy, 31(2), pp. 288-301.

Purohit, B. and R. Reddy (1999), 'Capital Formation in Indian Agriculture: Issues and Concerns’, NABARD, Occasional Paper 8. 


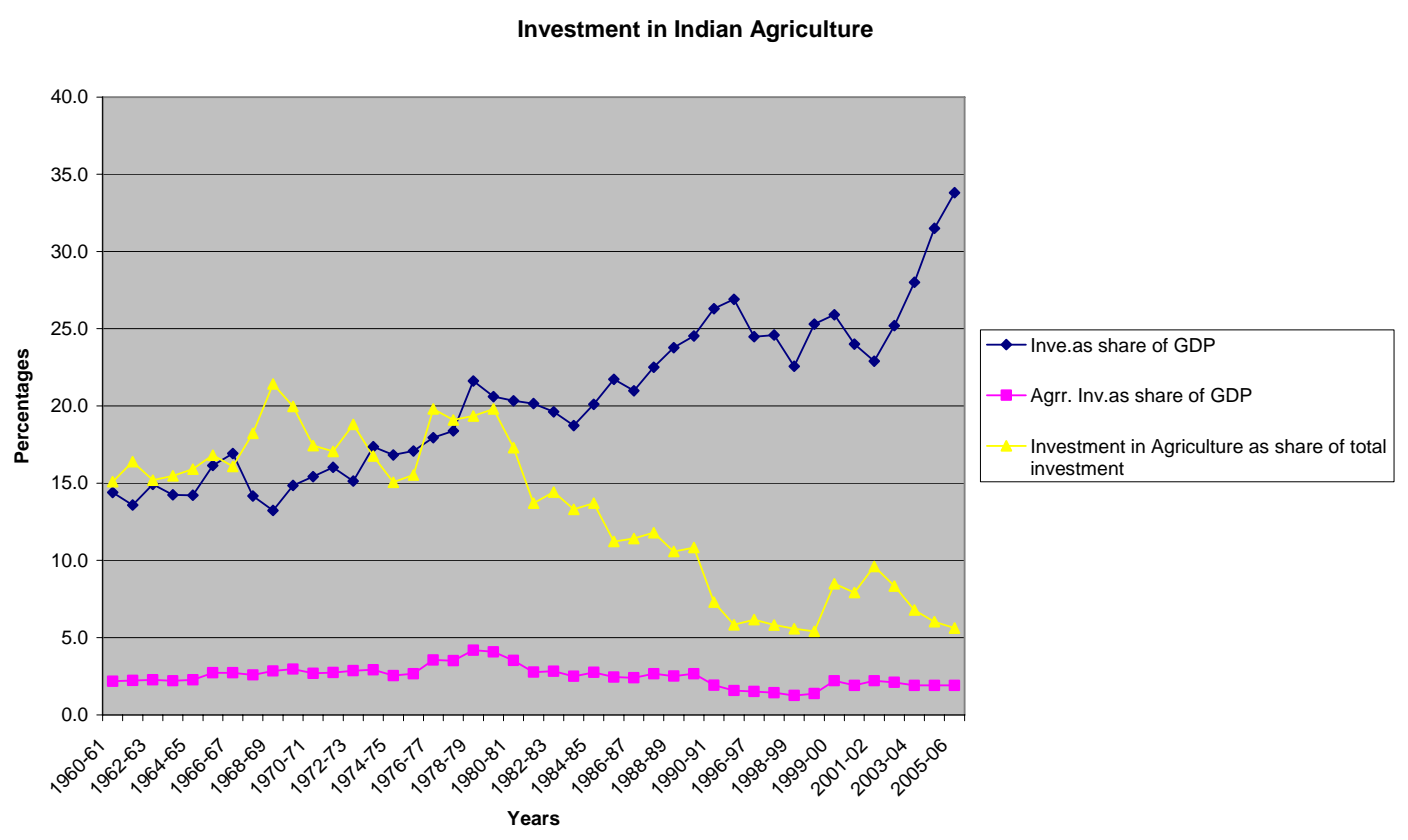

Figure1: Investment in Indian Agriculture

Source: Computed from Mullen et al. (2005)

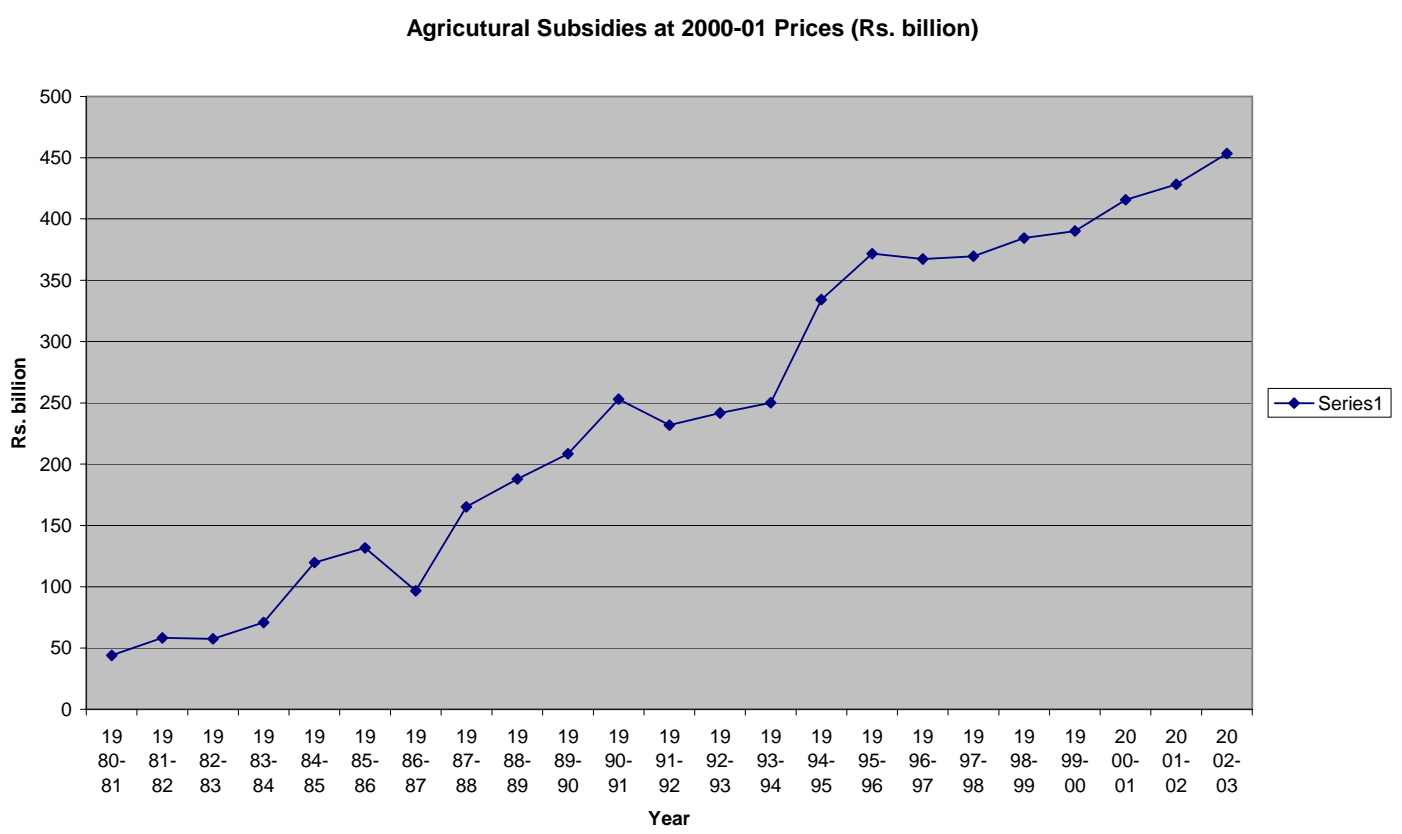

Figure 2: Agricultural Subsidies at Constant Prices

Source: Computed from Figures provided by Reserve Bank of India 


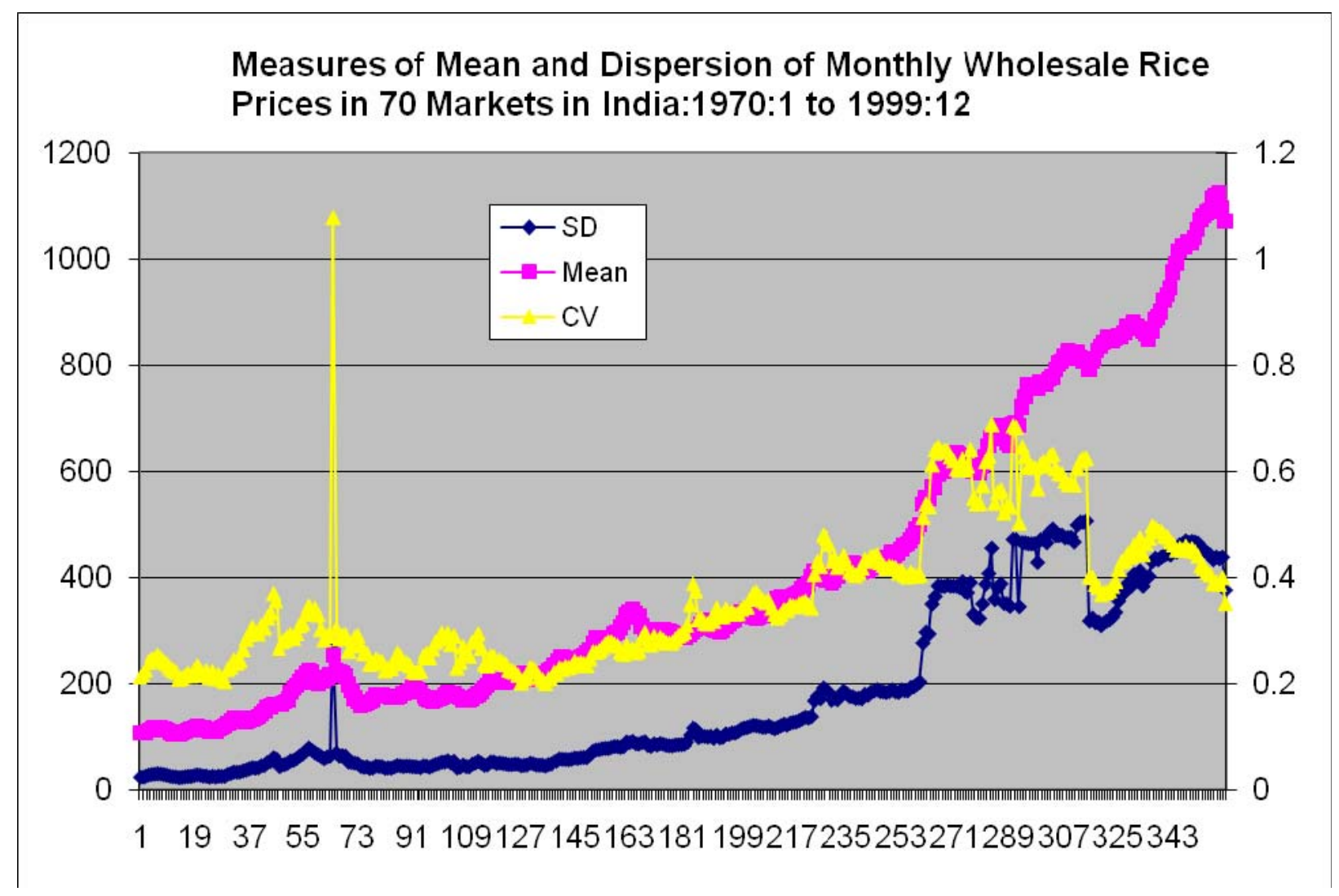

Figure 3: Measures of Mean and Dispersion of Monthly Wholesale Rice Prices in 70 markets in India: 1970:1 to 1999:12. (horizontal axis refers to elapsed months since 1970:1). 
Table 1: Nutritional Status of Adults in South Asia

\begin{tabular}{|l|c|c|c|c|c|c|c|c|}
\hline Country & \multicolumn{3}{|c|}{ Number of Undernourished Persons (Millions) } & \multicolumn{3}{c|}{ Prevalence of Undernourishment in Total Population (\%) } \\
\hline & $1990-92$ & $1995-97$ & $2000-2002$ & $2005-2007$ & $1990-92$ & $1995-97$ & $2000-2002$ & $2005-2007$ \\
\hline Bangladesh & 44.4 & 54.2 & 42.3 & 41.7 & 38 & 41 & 29 & 27 \\
\hline India & 172.4 & 162.7 & 200.6 & 237.7 & 20 & 17 & 19 & 21 \\
\hline Nepal & 4.2 & 4.4 & 4.6 & 4.5 & 21 & 20 & 18 & 20 \\
\hline Pakistan & 29.6 & 26.9 & 36.1 & 43.4 & 25 & 24 & 26 \\
\hline Sri Lanka & 4.8 & 4.5 & 3.9 & 3.8 & 28 & 25 & 20 \\
\hline
\end{tabular}

Source: FAO Statistical Tables

Table 2: The Incidence of Low weight, Over Weight and Obesity in South Asian Adults (\%)

\begin{tabular}{|c|c|c|c|c|c|c|c|c|c|c|c|}
\hline & \multirow{2}{*}{$\begin{array}{l}\text { Latest } \\
\text { Survey Year. } \\
\text { Age Range }\end{array}$} & \multirow{2}{*}{ Area } & \multicolumn{3}{|c|}{ Underweight } & \multicolumn{3}{|c|}{ Overweight } & \multicolumn{3}{|c|}{ Obesity } \\
\hline & & & Total & Male & Female & Total & Male & Female & Total & Male & Female \\
\hline \multirow{3}{*}{ Bangladesh } & 2007 & National & & & 29.7 & & & 11.8 & & & 1.7 \\
\hline & $15-49$ & Rural & & & & & & & & & \\
\hline & & Urban & & & & & & & & & \\
\hline \multirow{3}{*}{ India } & 2005-06 & National & & 33.7 & 35.6 & & 9.7 & 12.6 & & 1.3 & 2.8 \\
\hline & $15-49$ & Rural & & 38.4 & 40.6 & & 5.6 & 7.4 & & 0.6 & 1.3 \\
\hline & & Urban & & 26.5 & 25.0 & & 15.9 & 23.5 & & 2.4 & 6.1 \\
\hline \multirow{3}{*}{ Nepal } & 2006 & National & & & 24.4 & & & 8.6 & & & 0.9 \\
\hline & $15-49$ & Rural & & & 25.9 & & & 6.3 & & & 0.4 \\
\hline & & Urban & & & 16.6 & & & 20.7 & & & 3.7 \\
\hline \multirow{3}{*}{ Pakistan } & $1990-94$ & National & 31.2 & 30.8 & 31.6 & 14.4 & 11.3 & 17.5 & 3.4 & 1.6 & 5.2 \\
\hline & $15-100$ & Rural & & & & & & & & & \\
\hline & & Urban & & & & & & & & & \\
\hline
\end{tabular}

Source: FAO Statistics 
Table 3: Infant and Child Mortality in South Asia

\begin{tabular}{|l|c|c|c|c|c|c|c|c|}
\hline & \multicolumn{4}{|c|}{$\begin{array}{c}\text { Under 5 Child Mortality } \\
\text { Mortality per 1000 live births }\end{array}$} & \multicolumn{4}{c|}{$\begin{array}{c}\text { Infant Mortality Rate (0-1 year) } \\
\text { Mortality per 1000 live births }\end{array}$} \\
\hline & 1990 & 1995 & 2000 & 2008 & 1990 & 1995 & 2000 & 2008 \\
\hline Bangladesh & 149 & 122 & 91 & 54 & 103 & 86 & 67 & 43 \\
\hline India & 116 & 104 & 94 & 69 & 83 & 75 & 68 & 52 \\
\hline Nepal & 142 & 117 & 85 & 51 & 99 & 83 & 63 & 41 \\
\hline Pakistan & 130 & 121 & 108 & 89 & 101 & 94 & 85 & 72 \\
\hline Sri Lanka & 29 & 25 & 21 & 15 & 23 & 21 & 17 & 13 \\
\hline
\end{tabular}

Source: FAO Statistics

Table 4: Indicators of Undernutrition in Children Under the Age of Five Years.

\begin{tabular}{|c|c|c|c|c|c|c|c|c|c|c|c|}
\hline \multirow[b]{4}{*}{ Country } & \multicolumn{8}{|c|}{$\begin{array}{l}\text { Prevalence of undernutrition in children } \\
\text { under the age of five years (percent) }\end{array}$} & \multicolumn{3}{|c|}{$\begin{array}{c}\text { Percentage of children } \\
\text { over- weight }\end{array}$} \\
\hline & \multirow{3}{*}{$\begin{array}{c}\text { Latest } \\
\text { Survey } \\
\text { year }\end{array}$} & \multicolumn{2}{|c|}{ Underweight } & \multicolumn{2}{|c|}{ Stunting } & \multicolumn{2}{|c|}{ Wasting } & \multirow{3}{*}{$\begin{array}{l}\text { Age class } \\
\text { (in month) }\end{array}$} & \multirow{3}{*}{$\begin{array}{c}\text { Latest } \\
\text { Survey } \\
\text { year }\end{array}$} & \multirow{3}{*}{$\begin{array}{l}\text { more than } \\
+2 \text { s.d }\end{array}$} & \multirow{3}{*}{$\begin{array}{l}\text { Age class } \\
\text { (in month) }\end{array}$} \\
\hline & & Moderate & Severe & Moderate & Severe & Moderate & Severe & & & & \\
\hline & & $\begin{array}{l}\text { less than } \\
-2 \text { s.d }\end{array}$ & $\begin{array}{l}\text { less than } \\
-3 \text { s.d }\end{array}$ & $\begin{array}{l}\text { less than } \\
-2 \text { s.d }\end{array}$ & $\begin{array}{l}\text { less than } \\
-3 \text { s.d }\end{array}$ & $\begin{array}{l}\text { less than } \\
-2 \text { s.d }\end{array}$ & $\begin{array}{l}\text { less than } \\
-3 \mathrm{s.d}\end{array}$ & & & & \\
\hline Bangladesh & 2007 & 46 & 11 & 36 & 12 & 16 & 1 & $0-59$ & 2006 & 0.7 & $0-59$ \\
\hline India & 2005-06 & 48 & 15 & 43 & 20 & 17 & 3 & $0-59$ & 2005-06 & 1.9 & $0-59$ \\
\hline Nepal & 2006 & 45 & 10 & 43 & 15 & 12 & 1 & $0-59$ & 2006 & 0.6 & $0-59$ \\
\hline Pakistan & $2001-02$ & 38 & 13 & 37 & 18 & 13 & 3 & $0-59$ & 2001 & 4.8 & $0-59$ \\
\hline Sri Lanka & 2000 & 29 & - & 14 & - & 14 & - & $3-59$ & 2009 & 0.8 & $0-59$ \\
\hline
\end{tabular}

Source: FAO Statistics. 
Food Security and Small Landholders in South Asia

Table 5: Comparable Estimates of Poverty and Inequality — All India and Major States

\begin{tabular}{|c|c|c|c|c|c|c|c|c|c|c|c|c|c|c|c|c|}
\hline & \multicolumn{16}{|c|}{ Rural } \\
\hline & \multicolumn{4}{|c|}{$\begin{array}{c}\text { Head Count ratio (\% HCR) } \\
\text { Uniform } 30 \text { day rule } \\
\text { (using official poverty lines) }\end{array}$} & \multicolumn{4}{|c|}{$\begin{array}{c}\text { Poverty Gap } \\
\text { using official poverty lines }\end{array}$} & \multicolumn{4}{|c|}{$\begin{array}{l}\text { Squared Poverty Gap } \\
\text { using official poverty lines }\end{array}$} & \multicolumn{4}{|c|}{ Gini Coefficient } \\
\hline & 1983 & $\begin{array}{c}1987- \\
88 \\
\end{array}$ & $\begin{array}{c}1993- \\
94\end{array}$ & $\begin{array}{c}2004- \\
05\end{array}$ & 1983 & $1987-88$ & $\begin{array}{c}1993- \\
94\end{array}$ & \begin{tabular}{|c|}
$2004-$ \\
05
\end{tabular} & 1983 & $1987-88$ & 1993-94 & 2004-05 & 1983 & $\begin{array}{c}1987- \\
88 \\
\end{array}$ & \begin{tabular}{|c|}
$1993-$ \\
94
\end{tabular} & $\begin{array}{c}2004- \\
05\end{array}$ \\
\hline All-India & 46.5 & 39.0 & 37.2 & 28.7 & 12.36 & 9.29 & 8.5 & 5.8 & 4.87 & 3.23 & 2.84 & 1.76 & 30.4 & 29.9 & 28.6 & 30.5 \\
\hline $\begin{array}{l}\text { Andhra } \\
\text { Pradesh }\end{array}$ & 26.8 & 21.0 & 15.9 & 10.8 & 5.86 & 4.35 & 2.9 & 2.0 & 2.00 & 1.41 & 0.87 & 0.65 & 29.7 & 30.9 & 29.0 & 29.4 \\
\hline \begin{tabular}{|l|} 
Assam \\
\end{tabular} & 44.6 & 39.4 & 45.2 & 21.7 & 8.75 & 7.45 & 8.3 & 3.5 & 2.63 & 2.04 & 2.21 & 0.90 & 20.0 & 23.0 & 17.9 & 19.9 \\
\hline Jharkhand & 65.5 & 52.8 & 62.3 & 42.9 & 22.0 & 13.56 & 16.2 & 8.9 & 9.8 & 5.03 & 5.59 & 2.55 & 27.2 & 26.6 & 23.4 & 22.7 \\
\hline Bihar & 64.7 & 54.2 & 56.6 & 42.2 & 19.54 & 12.74 & 14.2 & 8.3 & 7.86 & 4.32 & 4.9 & 2.30 & 25.9 & 25.2 & 22.2 & 20.7 \\
\hline Gujarat & 28.9 & 28.3 & 22.2 & 19.4 & 5.64 & 5.44 & 4.1 & 3.4 & 1.69 & 1.59 & 1.16 & 0.91 & 26.8 & 26.1 & 24.0 & 27.3 \\
\hline Haryana & 21.9 & 15.3 & 28.3 & 13.6 & 4.28 & 3.62 & 5.6 & 2.2 & 1.37 & 1.30 & 1.75 & 0.61 & 28.5 & 29.2 & 31.4 & 34.0 \\
\hline $\begin{array}{r}\text { Himachal } \\
\text { Pradesh } \\
\end{array}$ & 17.0 & 16.7 & 30.4 & 10.9 & 3.58 & 2.63 & 5.6 & 1.5 & 1.16 & 0.71 & 1.62 & 0.35 & & 27.1 & 28.4 & 31.1 \\
\hline Karnataka & 36.3 & 32.6 & 30.1 & 20.0 & 9.73 & 7.88 & 6.3 & 2.7 & 3.69 & 2.80 & 2.01 & 0.63 & 30.8 & 29.7 & 27.0 & 26.5 \\
\hline Kerala & 39.6 & 29.3 & 25.4 & 13.2 & 9.98 & 6.30 & 5.6 & 2.8 & 3.62 & 2.05 & 1.85 & 0.98 & 32.0 & 32.1 & 30.1 & 38.3 \\
\hline Chattisgarh & 50.6 & 46.7 & 44.4 & 42.0 & 12.49 & 10.38 & 8.6 & 9.4 & 4.47 & 3.36 & 2.47 & 3.43 & 24.4 & 24.5 & 21.7 & 29.8 \\
\hline $\begin{array}{l}\text { Madhya } \\
\text { Pradesh }\end{array}$ & 49.0 & 40.1 & 39.2 & 35.8 & 13.95 & 10.64 & 9.8 & 7.8 & 5.54 & 3.97 & 3.58 & 2.31 & 31.5 & 30.6 & 30.0 & 26.8 \\
\hline Maharashtra & 45.9 & 40.9 & 37.9 & 30.0 & 11.95 & 9.56 & 9.3 & 6.4 & 4.3 & 3.21 & 3.35 & 1.99 & 29.1 & 31.2 & 30.7 & 31.2 \\
\hline Orissa & 68.5 & 58.7 & 49.8 & 46.9 & 22.72 & 16.30 & 12.0 & 12.1 & 10.17 & 6.24 & 4.07 & 4.24 & 27.0 & 26.9 & 24.6 & 28.5 \\
\hline Punjab & 14.3 & 12.8 & 11.7 & 10.0 & 3.03 & $\begin{array}{ll}1.97 \\
\end{array}$ & 1.9 & 1.3 & 1.06 & 0.51 & 0.48 & 0.26 & 29.2 & 29.7 & 28.1 & 29.5 \\
\hline Rajasthan & 35.0 & 33.3 & 26.4 & 19.0 & 9.65 & 8.64 & 5.2 & 2.9 & 3.81 & 3.40 & 1.56 & 0.72 & 34.7 & 31.5 & 26.5 & 25.1 \\
\hline Uttaranchal & 25.2 & 13.2 & 24.8 & 14.9 & 4.0 & 1.99 & 4.4 & 1.9 & 1.04 & 0.46 & 1.08 & 0.42 & 29.2 & 28.3 & 24.4 & 28.5 \\
\hline Uttar Pradesh & 47.8 & 43.3 & 43.1 & 33.9 & 12.70 & 10.25 & 10.6 & 6.7 & 4.7 & 3.4 & 3.64 & 1.93 & 28.9 & 28.5 & 28.3 & 29.0 \\
\hline \multirow[t]{4}{*}{\begin{tabular}{|l|} 
West Bengal \\
\end{tabular}} & 63.6 & 48.8 & 41.2 & 28.5 & 21.06 & 11.58 & 8.3 & 5.4 & 9.46 & 3.99 & 2.45 & 1.42 & 30.0 & 25.8 & 25.4 & 27.4 \\
\hline & \multicolumn{16}{|c|}{ Urban } \\
\hline & \multicolumn{4}{|c|}{$\begin{array}{l}\text { Head Count ratio (\% HCR) } \\
\text { Uniform } 30 \text { day rule } \\
\text { (using official poverty lines) }\end{array}$} & \multicolumn{4}{|c|}{$\begin{array}{c}\text { Poverty Gap } \\
\text { using official poverty lines }\end{array}$} & \multicolumn{4}{|c|}{$\begin{array}{l}\text { Squared Poverty Gap } \\
\text { using official poverty lines }\end{array}$} & \multicolumn{4}{|c|}{ Gini Coefficient } \\
\hline & 1983 & \begin{tabular}{|c|}
$1987-$ \\
88 \\
\end{tabular} & $\begin{array}{c}1993- \\
94\end{array}$ & $\begin{array}{c}2004- \\
05 \\
\end{array}$ & 1983 & 1987-88 & \begin{tabular}{|c|}
$1993-$ \\
94 \\
\end{tabular} & \begin{tabular}{|c|}
$2004-$ \\
05 \\
\end{tabular} & 1983 & $1987-88$ & |1993-94 & |2004-05 & 1983 & $\begin{array}{c}1987- \\
88 \\
\end{array}$ & \begin{tabular}{|c|}
$1993-$ \\
94 \\
\end{tabular} & $\begin{array}{c}2004- \\
05 \\
\end{array}$ \\
\hline All-India & 43.6 & \begin{tabular}{|r|}
38.7 \\
\end{tabular} & 32.6 & 25.9 & 11.4 & 10.2 & 8.0 & \begin{tabular}{|l|}
6.2 \\
\end{tabular} & 4.4 & 3.8 & 2.9 & 2.0 & 33.9 & 35.0 & \begin{tabular}{|l|}
34.4 \\
\end{tabular} & 37.6 \\
\hline \begin{tabular}{|l|} 
Andhra \\
Pradesh \\
\end{tabular} & 41.2 & 41.1 & 38.8 & 27.1 & 10.9 & 10.6 & 9.3 & 6.1 & 4.1 & 3.9 & 3.2 & 1.9 & 33.2 & 36.1 & 32.3 & 37.6 \\
\hline \begin{tabular}{|l|} 
Assam \\
\end{tabular} & 25.9 & 11.3 & 7.9 & 3.7 & 5.6 & 1.5 & 0.9 & 0.5 & 1.7 & 0.3 & 0.2 & 0.1 & 26.1 & 31.0 & 29.0 & 32.1 \\
\hline Jharkhand & 40.5 & 34.6 & 26.5 & 20.7 & 10.9 & 7.8 & 5.2 & 4.7 & 4.2 & 2.6 & 1.6 & 1.5 & 30.9 & 32.1 & 32.5 & 35.5 \\
\hline Bihar & 61.6 & 63.8 & 40.7 & 38.1 & 18.5 & 16.6 & 9.7 & 9.3 & 7.1 & 5.9 & 3.4 & 3.0 & 28.5 & 26.6 & 28.2 & 33.3 \\
\hline Gujarat & 41.9 & 38.5 & 28.3 & 14.2 & 9.7 & 8.2 & 6.2 & 2.5 & 3.6 & 2.6 & 2.0 & 0.7 & 28.5 & 27.8 & 29.1 & 31.0 \\
\hline Haryana & 26.4 & 18.4 & 16.5 & 15.6 & 5.8 & 3.6 & 3.0 & 3.2 & 1.9 & 1.1 & 0.9 & 1.0 & 34.8 & 28.7 & 28.4 & 36.5 \\
\hline $\begin{array}{c}\text { Himachal } \\
\text { Pradesh }\end{array}$ & 11.0 & 7.2 & 9.3 & 5.0 & 2.8 & 0.7 & 1.2 & 1.0 & 1.1 & 0.1 & 0.3 & 0.3 & 35.8 & 29.2 & 46.2 & 32.6 \\
\hline Karnataka & 43.6 & 49.2 & 39.9 & 33.3 & 13.3 & 14.1 & 11.4 & 8.9 & 5.5 & 5.7 & 4.4 & 3.1 & 34.2 & 34.0 & 31.9 & 36.8 \\
\hline Kerala & 48.0 & 38.7 & 24.3 & 20.6 & 14.7 & 10.0 & 5.5 & 4.7 & 6.2 & 3.9 & 1.9 & 1.6 & 38.9 & 36.9 & 34.3 & 41.0 \\
\hline Chattisgarh & 50.7 & 36.0 & 44.2 & 40.7 & 14.5 & 9.8 & 11.5 & 12.9 & 5.6 & 3.6 & 4.1 & 5.4 & 32.2 & 32.1 & 30.6 & 44.0 \\
\hline $\begin{array}{l}\text { Madhya } \\
\text { Pradesh }\end{array}$ & 56.1 & 50.0 & 49.0 & 42.3 & 16.1 & 14.5 & 13.9 & 12.4 & 6.2 & 5.6 & 5.3 & 4.8 & 29.8 & 33.3 & 33.6 & 39.7 \\
\hline Maharashtra & 41.1 & 40.5 & 35.0 & 32.8 & 12.1 & 12.4 & 10.2 & 9.2 & 4.9 & 5.2 & 4.2 & 3.5 & 34.6 & 34.8 & 35.7 & 37.8 \\
\hline Orissa & 54.0 & 42.6 & 40.6 & 43.7 & 16.7 & 11.1 & 11.4 & 14.1 & 7.1 & 4.2 & 4.3 & 5.8 & 29.0 & 31.0 & 30.7 & 35.4 \\
\hline Punjab & 22.9 & 13.7 & 10.9 & 5.0 & 5.9 & 2.3 & 1.7 & 0.6 & 2.3 & 0.6 & 0.4 & 0.1 & 33.9 & 28.8 & 28.1 & 40.3 \\
\hline Rajasthan & 41.2 & 37.9 & 31.0 & 28.5 & 11.5 & 9.6 & 7.0 & 6.2 & 4.7 & 3.4 & 2.2 & 1.9 & 33.9 & 34.6 & 29.3 & 37.2 \\
\hline Uttaranchal & 22.4 & 20.4 & 12.7 & 17.0 & 5.9 & 4.2 & 3.2 & 3.0 & 2.0 & 1.2 & 0.9 & 0.7 & 30.5 & 35.1 & 27.5 & 32.9 \\
\hline Uttar Pradesh & 52.7 & 46.4 & 36.1 & 30.7 & 15.1 & 12.7 & 9.3 & 7.2 & 5.9 & 4.7 & 3.4 & 2.3 & 31.5 & 33.5 & 32.6 & 36.9 \\
\hline West Bengal & 33.5 & $\begin{array}{l}33.7 \\
\end{array}$ & 22.9 & 15.4 & 8.5 & 7.4 & 4.5 & 2.6 & 3.2 & 2.4 & 1.4 & 0.6 & 33.5 & 34.6 & 33.9 & 38.3 \\
\hline
\end{tabular}

Notes: N.B. Results for 1983, 1987-88, 1993-94 are based on household level data and those for 2004-05 on group data.

NSS dates chosen refer to thick samples which yield more reliable estimates.

$1999-00$ is omitted because of problems of comparability.

Samples in intermediate years are small and are hence omitted from the analysis.

Source: Himanshu (2007). 
Table 6: Poverty and Nutritional Profile of Small farmers in India in 1993-94 and 2004-05

\begin{tabular}{|c|c|c|c|c|c|c|}
\hline $\begin{array}{l}\text { State/All India } \\
\text { (Column 1) }\end{array}$ & $\begin{array}{l}\% \text { of rural } \\
\text { households } \\
\text { who were } \\
\text { small farmers } \\
\text { in 1993-94 } \\
\text { (Column 2) }\end{array}$ & $\begin{array}{c}\text { Small farmers as } \\
\% \text { of rural poor } \\
\text { households } \\
\text { in 1993-94 } \\
\text { (Column 3) }\end{array}$ & \begin{tabular}{|c|} 
Small and also \\
calorie deficient \\
farming house- \\
holds as \% of \\
rural households \\
in 1993-94 \\
(Column 4) \\
\end{tabular} & $\begin{array}{l}\% \text { of rural } \\
\text { households } \\
\text { who were } \\
\text { small farmers } \\
\text { in 2004-05 } \\
\text { (Column } 5 \text { ) }\end{array}$ & $\begin{array}{l}\text { Small farmers } \\
\text { as } \% \text { of rural } \\
\text { poor } \\
\text { households } \\
\text { in 2004-05 } \\
\text { (Column } 6 \text { ) }\end{array}$ & $\begin{array}{l}\text { Small and also } \\
\text { calorie deficient } \\
\text { farming house- } \\
\text { holds as \% of } \\
\text { rural households } \\
\text { in 2004-05 } \\
\text { (Column 7) }\end{array}$ \\
\hline Andhra Pradesh & 89.27 & 91.07 & 91.05 & 90.48 & 91.88 & 90.95 \\
\hline Arunachal Pradesh & 86.20 & 94.06 & 87.57 & 78.17 & 77.17 & 82.73 \\
\hline Assam & 79.83 & 84.95 & 81.75 & 77.59 & 90.53 & 80.83 \\
\hline Bihar & 87.42 & 90.08 & 90.68 & 91.34 & 97.65 & 93.54 \\
\hline Jharkhand & & & & 87.92 & 90.83 & 89.13 \\
\hline Goa & 97.70 & 100.00 & 98.99 & 97.34 & 100.00 & 95.56 \\
\hline Gujarat & 87.02 & 86.60 & 88.19 & 87.72 & 92.94 & 89.61 \\
\hline Haryana & 87.31 & 88.82 & 93.61 & 89.11 & 98.04 & 94.84 \\
\hline Himachal Pradesh & 84.32 & 89.48 & 89.24 & 90.30 & 94.74 & 93.08 \\
\hline Jammu and Kashmir & 74.76 & 70.46 & 89.58 & 87.17 & 91.07 & 91.61 \\
\hline Karnataka & 83.68 & 82.42 & 87.68 & 85.57 & 87.12 & 86.52 \\
\hline Kerala & 95.35 & 98.57 & 97.07 & 96.07 & 98.94 & 97.67 \\
\hline Madhya Pradesh & 79.93 & 81.18 & 85.87 & 79.47 & 81.96 & 81.07 \\
\hline Chattisgarh & & & & 82.83 & 83.97 & 85.72 \\
\hline Maharashtra & 83.82 & 85.07 & 85.92 & 84.64 & 87.33 & 86.57 \\
\hline Manipur & 81.44 & 74.17 & 85.96 & 84.97 & 69.30 & 84.93 \\
\hline Meghalaya & 80.78 & 81.66 & 81.20 & 81.91 & 75.35 & 82.02 \\
\hline Mizoram & 66.14 & 74.41 & 67.91 & 81.64 & 90.27 & 82.39 \\
\hline Nagaland & 49.41 & 100.0 & 65.47 & 74.50 & 84.76 & 79.24 \\
\hline Orissa & 85.75 & 87.47 & 90.13 & 86.92 & & 87.85 \\
\hline Punjab & 89.17 & 98.53 & 95.85 & 92.63 & 98.93 & 96.61 \\
\hline Rajasthan & 81.27 & 80.23 & 89.59 & 82.64 & 85.59 & 86.83 \\
\hline Sikkim & 81.38 & 88.38 & 81.51 & 94.99 & 100.00 & 94.10 \\
\hline Tamilnadu & 92.78 & 95.05 & 93.33 & 93.98 & 95.52 & 93.55 \\
\hline Tripura & 88.23 & 94.81 & 88.15 & 95.00 & 98.31 & 94.79 \\
\hline Uttar Pradesh & 84.96 & 87.91 & 90.61 & 87.66 & 93.31 & 91.04 \\
\hline Uttaranachal & & & & 94.46 & 96.96 & 96.90 \\
\hline West Bengal & 92.39 & 96.74 & 95.99 & 94.34 & 97.66 & 95.19 \\
\hline $\begin{array}{l}\text { Andaman and Nicobar } \\
\text { Islands }\end{array}$ & 91.55 & 100.00 & 90.80 & & & \\
\hline Chandigarh & 97.38 & 100.00 & 99.07 & & & \\
\hline Dadar and Nagar Haveli & 87.06 & 87.40 & 83.34 & 84.07 & 84.88 & 73.30 \\
\hline Daman and Diu & 95.31 & 100.00 & 94.13 & 96.86 & & 94.68 \\
\hline Delhi & 98.14 & 100.00 & 100.00 & 98.93 & 100.00 & 100.00 \\
\hline Lakshwadeep & 99.91 & & 100.00 & & & \\
\hline Pondicherry & 96.71 & 100.00 & 98.78 & 96.50 & 100.00 & 97.50 \\
\hline All India & 86.52 & 88.54 & 90.23 & 88.19 & 91.42 & 90.05 \\
\hline
\end{tabular}

Source: Author's calculation based on NSS data for 50th round (1993-94) and 615t round (2004-05) for rural India 
Table 7: Real GDP Growth Rates in South Asia

\begin{tabular}{|l|c|c|c|c|c|c|c|c|c|c|}
\hline & $\begin{array}{c}\text { Average } \\
1961-70\end{array}$ & $\begin{array}{c}\text { Average } \\
1971-80\end{array}$ & $\begin{array}{c}\text { Average } \\
1981-90\end{array}$ & $\begin{array}{c}\text { Average } \\
1991-00\end{array}$ & $\begin{array}{c}\text { Average } \\
2001-04\end{array}$ & 2005 & 2006 & 2007 & 2008 & 2009 \\
\hline Bangladesh & $3.84^{\mathrm{a}}$ & 1.04 & 3.72 & 4.79 & 5.32 & 6.0 & 6.6 & 6.4 & 6.2 & 5.9 \\
\hline India & 4.12 & 3.09 & 5.57 & 5.5 & 6.42 & 9.4 & 9.7 & 9.1 & 7.1 & 7.2 \\
\hline Nepal & 2.52 & 2.11 & 4.78 & 4.99 & 3.37 & 3.1 & 3.7 & 3.3 & 5.3 & 4.7 \\
\hline Pakistan & 7.25 & 4.72 & 6.3 & 3.97 & 4.35 & 7.7 & 6.2 & 6.0 & 6.0 & 2.0 \\
\hline Sri Lanka & 4.56 & 4.42 & 4.2 & 5.22 & 3.45 & 6.2 & 7.7 & 6.8 & 6.0 & 3.5 \\
\hline $\begin{array}{l}\text { Unweighted } \\
\text { Average for } \\
\text { these countries }\end{array}$ & 4.45 & 3.076 & 4.91 & 4.89 & 4.58 & 6.48 & 6.78 & 6.32 & 6.12 & 4.66 \\
\hline
\end{tabular}

Note: a: 1962-1970

Source: For 2009 (estimated by) UNESCAP: Economic and Social Survey of Asia and the Pacific 2010. For all other years World Development Indicators 2009.

Table 8: Rate of growth at factor cost at 1999-2000 prices (per cent)

\begin{tabular}{|l|c|c|c|c|c|c|}
\hline & $\begin{array}{l}2000-01 \text { to } \\
2007-08 \\
\text { average }\end{array}$ & $2005-06$ & $2006-07$ & $2007-08$ & $2008-09$ & $2009-10$ \\
\hline Agriculture, Forestry and Fishing & 2.9 & 5.2 & 3.7 & 4.7 & 1.6 & -0.2 \\
\hline Mining and Quarrying & 4.9 & 1.3 & 8.7 & 3.9 & 1.6 & 8.7 \\
\hline Manufacturing & 7.8 & 9.6 & 14.9 & 10.3 & 3.2 & 8.9 \\
\hline Electricity, Gas and Water Supply & 4.8 & 6.6 & 10.0 & 8.5 & 3.9 & 8.2 \\
\hline Construction & 10.6 & 12.4 & 10.6 & 10.0 & 5.9 & 6.5 \\
\hline Trade, Hotels and Restaurants & $10.3^{\mathrm{a}}$ & 12.4 & 11.2 & 9.5 & 5.3 & 8.3 \\
\hline $\begin{array}{l}\text { Transport, Storage and } \\
\text { Communication }\end{array}$ & 11.5 & 12.6 & 13.0 & 11.6 & \\
\hline $\begin{array}{l}\text { Financing, Insurance, Real Estate } \\
\text { and Business Services }\end{array}$ & 8.8 & 12.8 & 14.5 & 13.2 & 10.1 & 9.9 \\
\hline $\begin{array}{c}\text { Community, Social and Personal } \\
\text { Services }\end{array}$ & 5.8 & 7.6 & 2.6 & 6.7 & 13.9 & 8.2 \\
\hline GDP at Factor Cost & 7.3 & 9.5 & 9.7 & 9.2 & 6.7 & 7.2 \\
\hline
\end{tabular}

N.B. $a=$ This refers to Trade, Hotels, Restaurants, Transport, Storage \& Communication

Source: Economic Survey, Ministry of Finance, Government of India, 2009-10. 
Table 9 : Economic Growth and Poverty Reduction in Select Asian Countries (1995-2005)

\begin{tabular}{|l|c|c|c|}
\hline Country & $\begin{array}{c}\text { Average annual growth } \\
\text { of per capita GDP }\end{array}$ & $\begin{array}{c}\text { Annual rate of poverty } \\
\text { reduction (PPP \$0.75 a } \\
\text { day ultra poverty line) }\end{array}$ & $\begin{array}{c}\text { Ratio of annual rate of } \\
\text { poverty reduction to annual } \\
\text { per capita GDP growth rate }\end{array}$ \\
\hline India & $4.9 \%$ & $-2.6 \%$ & -0.5 \\
\hline Bangladesh & $3.7 \%$ & $-3.9 \%$ & -1.1 \\
\hline Sri Lanka & $3.4 \%$ & $-10.3 \%$ & -3.1 \\
\hline Viet Nam & $6.2 \%$ & $-13.5 \%$ & -2.2 \\
\hline
\end{tabular}

Source: IFPRI 2010

Table 10: Average Growth Rates of Area, Production \& Yield under Foodgrains, Non-fodgrains \& All Crops

\begin{tabular}{|l|c|c|c|c|c|c|c|c|c|}
\cline { 2 - 10 } \multicolumn{1}{c|}{} & \multicolumn{3}{c|}{ Foodgrains } & \multicolumn{3}{c|}{ Non-foodgrains } & \multicolumn{3}{c|}{ All crops } \\
\cline { 2 - 10 } & Area & Production & Yield & Area & Production & Yield & Area & Production & Yield \\
\hline $\begin{array}{l}\text { 1951-52 to } \\
1993-94\end{array}$ & 0.59 & 3.52 & 2.77 & 1.77 & 3.85 & 1.95 & 0.81 & 3.47 & 1.96 \\
\hline $\begin{array}{l}\text { 1993-94 to } \\
2007-08\end{array}$ & 0.12 & 2.09 & 1.8 & 0.85 & 3.29 & 0.29 & 0.28 & 2.66 & 0.32 \\
\hline $\begin{array}{l}1951-52 \text { to } \\
1959-60\end{array}$ & 0.92 & 5.08 & 2.89 & 2.95 & 4.15 & 1.17 & 2.12 & 4.16 & 1.19 \\
\hline $\begin{array}{l}1960-61 \text { to } \\
1969-70\end{array}$ & 0.67 & 3.25 & 2.41 & 0.85 & 6.29 & 3.44 & 0.7 & 4.7 & 3.41 \\
\hline $\begin{array}{l}1970-71 \text { to } \\
1979-80\end{array}$ & 0.19 & 1.58 & 1.18 & 1.18 & 0.38 & 0.71 & 0.36 & 0.69 & 0.68 \\
\hline $\begin{array}{l}1980-81 \text { to } \\
1989-90\end{array}$ & 0.19 & 3.5 & 4.62 & 1.92 & 5.77 & 2.98 & 0.53 & 5.29 & 2.91 \\
\hline $\begin{array}{l}1990-91 \text { to } \\
1993-94\end{array}$ & 0.27 & 1.96 & 2.72 & 2.53 & 0.95 & 0.84 & -0.04 & 1.26 & 0.87 \\
\hline $\begin{array}{l}1951-52 \text { to } \\
1989-90\end{array}$ & 0.73 & 3.68 & 2.77 & 1.69 & 4.15 & 2.07 & 0.9 & 3.7 & 2.07 \\
\hline $\begin{array}{l}1990-91 \text { to } \\
2007-08\end{array}$ & 0.05 & 2.03 & 1.94 & 1.1 & 2.91 & 0.14 & 0.2 & 2.41 & 0.17 \\
\hline
\end{tabular}

Source: Author's computation based on Reserve Bank of India' Handbook of Statistics on the Indian Economy. 
Table 11: Production of Selected Kharif Crops (million tonnes)

\begin{tabular}{|l|c|c|c|c|}
\hline & $\begin{array}{c}2007-08 \\
\left(4^{\text {th }} \text { advance }\right. \\
\text { Estimates })\end{array}$ & $\begin{array}{c}2008-09 \\
\text { (4th advance } \\
\text { estimates })\end{array}$ & $\begin{array}{c}2009-10 \\
\left(1^{\text {st }} \text { advance }\right. \\
\text { estimates })\end{array}$ & $\begin{array}{c}\text { Difference between } \\
2009-10 \text { and 2007-08 }\end{array}$ \\
\hline Coarse cereals & 31.89 & 28.34 & 22.76 & -9.13 \\
\hline Cereals & 114.55 & 112.92 & 94.41 & -20.14 \\
\hline Pulses & 6.40 & 4.78 & 4.42 & -1.98 \\
\hline Foodgrains & 120.95 & 117.70 & 98.83 & -22.12 \\
\hline Oilseeds & 20.71 & 17.88 & 15.23 & -5.48 \\
\hline
\end{tabular}

Source: Economic Survey, Government of India, 2010

Table 12: Growth of Yield of Foodgrains ( $\mathrm{kg} / \mathrm{hectare}$ ) per cent per year

\begin{tabular}{|l|c|c|c|c|c|c|}
\cline { 2 - 7 } \multicolumn{1}{c|}{ Year } & Rice & Wheat & $\begin{array}{c}\text { Coarse } \\
\text { Cereals }\end{array}$ & $\begin{array}{c}\text { Total } \\
\text { Cereals }\end{array}$ & Pulses & $\begin{array}{c}\text { Total } \\
\text { Foodgrains }\end{array}$ \\
\hline $1950 \mathrm{~s}$ & $4.30 \%$ & $2.08 \%$ & $3.01 \%$ & $3.27 \%$ & $1.45 \%$ & $2.89 \%$ \\
\hline $1960 \mathrm{~s}$ & $1.91 \%$ & $5.25 \%$ & $1.30 \%$ & $2.33 \%$ & $2.60 \%$ & $2.41 \%$ \\
\hline $1970 \mathrm{~s}$ & $0.73 \%$ & $2.02 \%$ & $1.68 \%$ & $1.62 \%$ & $-2.57 \%$ & $1.18 \%$ \\
\hline $1980 \mathrm{~s}$ & $5.45 \%$ & $4.17 \%$ & $4.01 \%$ & $4.74 \%$ & $4.02 \%$ & $4.62 \%$ \\
\hline $1990 \mathrm{~s}$ & $1.36 \%$ & $2.87 \%$ & $2.03 \%$ & $2.38 \%$ & $1.82 \%$ & $2.43 \%$ \\
\hline 2000 s till 2007-08 & $1.79 \%$ & $0.09 \%$ & $4.74 \%$ & $1.64 \%$ & $0.59 \%$ & $1.32 \%$ \\
\hline $1950-51$ to 2007-08 & $2.59 \%$ & $2.85 \%$ & $2.72 \%$ & $2.69 \%$ & $1.34 \%$ & $2.51 \%$ \\
\hline
\end{tabular}

N.B. * Till 2007-08

Source: Reserve Bank of India 
Table 13: Growth of Yield of Non-Foodgrains ( $\mathrm{kg} / \mathrm{hectare)}$ per cent per year

\begin{tabular}{|c|c|c|c|c|c|c|c|c|c|c|}
\hline & \multicolumn{4}{|c|}{ Oilseeds } & \multirow{2}{*}{ Sugarcane } & \multirow{2}{*}{ Tea } & \multirow{2}{*}{ Coffee } & \multirow{2}{*}{$\begin{array}{c}\text { Cotton } \\
\text { (Lint) }\end{array}$} & \multirow{2}{*}{$\begin{array}{l}\text { Jute \& } \\
\text { Mesta }\end{array}$} & \multirow{2}{*}{ Tobacco } \\
\hline & $\begin{array}{c}\text { Ground- } \\
\text { nut }\end{array}$ & $\begin{array}{l}\text { Rapeseed } \\
\& \text { Mustard }\end{array}$ & Soyabean & Total \# & & & & & & \\
\hline $1950 \mathrm{~s}$ & $-0.06 \%$ & $0.72 \%$ & & $0.23 \%$ & $1.26 \%$ & & & $0.28 \%$ & $0.34 \%$ & $0.30 \%$ \\
\hline $1960 \mathrm{~s}$ & $1.39 \%$ & $5.81 \%$ & & $1.96 \%$ & $3.62 \%$ & & & $4.82 \%$ & $1.77 \%$ & $0.94 \%$ \\
\hline 1970s & $3.35 \%$ & $0.48 \%$ & $7.95 \%$ & $0.77 \%$ & $0.19 \%$ & $2.40 \%$ & $4.21 \%$ & $3.99 \%$ & $0.71 \%$ & $3.34 \%$ \\
\hline $1980 \mathrm{~s}$ & $3.60 \%$ & $8.17 \%$ & $5.44 \%$ & $4.72 \%$ & $3.03 \%$ & $1.40 \%$ & $4.92 \%$ & $5.86 \%$ & $4.04 \%$ & $2.75 \%$ \\
\hline 1990s & $-0.29 \%$ & $2.96 \%$ & $4.68 \%$ & $1.77 \%$ & $0.85 \%$ & $0.32 \%$ & $7.12 \%$ & $-0.53 \%$ & $1.16 \%$ & $-0.73 \%$ \\
\hline $2000 \mathrm{~s}$ & $16.64 \%$ & $1.61 \%$ & $2.91 \%$ & $5.47 \%$ & $-0.49 \%$ & $-0.35 \%$ & $-2.55 \%$ & $11.27 \%$ & $1.72 \%$ & $2.47 \%$ \\
\hline $\begin{array}{l}1950-51 \text { to } \\
2007-08\end{array}$ & $3.74 \%$ & $3.40 \%$ & $5.30 \%$ & $2.42 \%$ & $1.48 \%$ & $0.97 \%$ & $3.73 \%$ & $4.11 \%$ & $1.64 \%$ & $1.48 \%$ \\
\hline
\end{tabular}

Source: Reserve Bank of India

Table 14: Comparative Crop Yields 2000-03 (tons per hectare)

\begin{tabular}{|l|c|c|c|}
\hline & India & Developing Countries & World \\
\hline Rice, paddy & 2.9 & 3.8 & 3.9 \\
\hline Wheat & 2.7 & 2.7 & 2.7 \\
\hline Sorghum & 0.8 & 1.1 & 1.3 \\
\hline Pulses & 0.6 & 0.7 & 0.8 \\
\hline Ground nuts & 0.9 & 1.4 & 1.4 \\
\hline Soybeans & 0.9 & 2.1 & 2.3 \\
\hline Cotton lint & 0.2 & 0.5 & 0.6 \\
\hline Sugar Cane & 67 & 64 & 65 \\
\hline
\end{tabular}

Source: FAO (2004)

Table 15: Unemployment in India, Current Daily Status Basis (percentages)

\begin{tabular}{|c|c|c|c|c|c|c|c|c|}
\hline & \multicolumn{2}{|c|}{ 1993-94 } & \multicolumn{2}{|c|}{ 1999-00 } & \multicolumn{2}{|c|}{ 2003-04 } & \multicolumn{2}{|c|}{ 2005-06 } \\
\hline & Rural & Urban & Rural & Urban & Rural & Urban & Rural & Urban \\
\hline Male & 5.6 & 6.7 & \multirow{2}{*}{7.21} & \multirow{2}{*}{7.65} & 9 & 8.1 & 8.3 & 7.9 \\
\hline Female & 5.6 & 10.5 & & & 9.3 & 11.7 & 7.5 & 10.1 \\
\hline
\end{tabular}

Source: National Sample Survey Organisation, Government of India, 2008 